\title{
The Impact of Refuse Disposal Dump Sites on the Spread of Intestinal Helminthiasis in Owerri Metropolis, IMO State, South Eastern Nigeria
}

\author{
Chidinma A Ikpeama ${ }^{1}$, Ifeanyi O. C. Obiajuru ${ }^{2} *$, Ann I. Ogomaka ${ }^{1}$ \\ ${ }^{1}$ Department of Animal \& Environmental Biology, Imo State University Owerri \\ ${ }^{2}$ Department of Medical, Microbiology \& Parasitology, Imo State University, Orlu Campus
}

\begin{abstract}
The impact of refuse disposal dump sites on the spread of intestinal helminthiasis in Owerri metropolis, south eastern Nigeria was studied between March and October, 2015. Thirty samples of waste materials from refuse dump sites at different parts of Owerri, 30 soil samples from cultivated gardens within 10meters radius from the refuse dump sites and 40 samples of vegetables (Telfairia occidentalis and Amaranthus hybridus) were collected in sterile containers. The samples were analysed using parasite concentration techniques and microscopic examination for ova and/or larvae of helminthes. The findings revealed presence of ova and larvae of 7 species of helminthes: Ascaris lumbricoides, Trichuris trichiura, Enterobius vermicularis, Taenia solium, Taenia saginata Hookworms and Strongyloides stercoralis in the test samples. Taenia solium and Taenia saginata were seen only in samples from refuse dump sites but none from garden soil and / or vegetable samples Statistical analysis of the data using ANOVA showed strong positive correlation $(p<0.0 .5)$ in the prevalence of intestinal helminthes between the refuse disposal dump sites and soil / vegetable samples collected from nearby cultivated farms and gardens. All the helminthes recovered from garden soil and vegetable samples were present in the refuse dump samples collected from the same area. The most prevalent helminth in each of the 3 test samples was Ascaris lumbricoides (46.7\% in refuse dump, 66.7\% in garden soil and $45 \%$ in vegetables). Amaranthus hybidus leaves harboured more helminthes than Telfairia occidentalis. This study showed that refuse dump sites located in different parts of owerri metropolis pose great public health challenge to the population. Farmers who work in nearby farm lands and consumers of the farm products such as vegetables constitute the primary risk group. Imo State Environmental protection agency (ISEPA) and Environmental transformation Cooperation (ENTRACO) should take advantage of this study and ensure prompt regular evacuation of the wastes to avoid spreading infections agents in the neighbourhood. Farmers working in nearby farmlands should wear boots and adopt other protective measures to prevent infections. Consumers of the farm products like vegetables should wash them thoroughly and cook them very well before consumption.
\end{abstract}

Keywords: Refuse - Dump, Farmland, Vegetables, Helminthes, Owerri, Imo State

\section{INTRODUCTION}

Soil transmitted helminth infections are among the most common human infections in Nigeria. Though they are widely distributed all over the world, the prevalence remains remarkably higher in developing and under developed countries including Nigeria. This has been blamed among other factors on the low level of sanitation, improper disposal of wastes, lack of potable water supply, inadequate monitoring and regulations of food processing and handling as well as low level of personal hygiene (Saka et al., 2006). Over I billion people in the world are infected by soil transmitted helminthes (Egwunyeenga and Ataikim, 2006). Children are at higher risks of infection than adults (WHO, 2003; WHO, 2010). Previous workers (Opara et al., 2011) have reported among other helminthes, Ascaris lumbricoides, Trichuris trichiura and hookworms as most common soil transmitted helminthes. Some workers (Ogwurike, et al., 2010) have blamed humid warm temperature, shade and contamination of soil with organic decomposing matter as major factors that favour the development and spread of these parasites. These conditions are more common in urban areas like Owerri, south eastern Nigeria, where wastes are disposed indiscriminately and are not promptly evacuated to safe dump sites. The organic wastes decompose polluting the environment and spread infective ova and larvae of helminthes among other parasites. The burden of disease associated 
with helminthes infection is enormous. It is estimated that Schistosoma and soil transmitted helminthes infection represent more than $55 \%$ of disease burden in the tropics

\section{Materials AND Methods}

\subsection{Study Area}

The study was carried out in Owerri, Imo State, south eastern Nigeria. Imo State situates on the latitude $5^{\mathrm{O}} 29^{\prime} \mathrm{N}$ and $7^{\mathrm{O}} 2^{\prime} \mathrm{E}$. It comprises of 3 geo - political zones: Owerri, Orlu and Okigwe. Owerri is the capital city and comprises of 3 local Government Areas: Owerri municipal council, Owerri west and Owerri North. It has a teaming population of old and young people from all walks of life.

\section{Collection, Processing and Examination of Samples}

The samples used for this study are household wastes collected from municipal waste dumps, soil samples collected from cultivated farm lands within 10m radius from the refuse dump sites and vegetables collected from nearby farms or garden. Thirty samples of waste materials from refuse dump sites at different parts of Owerri, 30 soil samples and 40 samples of vegetables (Telfairia occidentalis and Amaranthus hybridus) were collected in sterile containers between March and October, 2015. The samples were taken to the parasitology laboratory, Imo State University Teaching Hospital and analysed within 2 hours of collection.

$1 \mathrm{~g}$ of each refuse and soil sample was placed in sterile test tube and $10 \mathrm{ml}$ of sterile physiological saline was added. It was shaken to homogenize and sieved through a sterile $0.05 \mathrm{~mm}$ mesh gauze. $0.5 \mathrm{~g}$ of each vegetable sample was cut into small pieces and placed a sterile flask containing $10 \mathrm{ml}$ of sterile physiological saline. It was shaken and sieved through a sterile $0.05 \mathrm{~mm}$ mesh gauze. The filtrate of each sample was centrifuged at 3500rpm for 5minutes. The supernatant was decanted and the deposit was homogenized. 1 drop was placed on a clean glass slide, covered with coverslip and examined microscopically for ova and larvae of helminthes. Each sample was also processed and examined by parasite concentration techniques as in Obiajuru and Ozumba (2009).

\section{Data Analysis}

Data obtained from the study were analysed using two ways ANOVA at 5\% significant level. Simple percentage was used to estimate the prevalence rate of the parasites in the study area and chi-square $(\grave{\alpha} 2)$ was used to determine the significant difference in results obtained at $5 \%(\mathrm{p}<0.05)$ level of significance.

\section{RESUltS}

The findings of this study showed that 7 species of helminthes: Ascaris lumbricoides, Trichuris trichiura, Enterobius vermicularis, Taenia solium, Taenia saginata, Hookworms and Strongyloides stercoralis were isolated from the test samples. Out of 30 samples of refuse materials examined, 14 (46.7\%) had Ascaris lumbricoides, 12 (40\%) had hookworm, 6 (20\%) had Trichuris trichiura. Table 1 summarizes the prevalence of ova and larvae of helminthes in refuse materials around Owerri metropolis. Out of 30 soil samples from farmlands within 10 meters radius from the different refuse dump sites, 20 (66.7\%) had Ascaris lumbricoides, 17 (56.7\%) had hookworms. Table 2 summarizes the prevalence of helminthes in farmland soil samples. Out of 40 vegetable samples examined, 18 (45\%) had Ascaris lumbricoides, 20 (50\%) ad hookworms. Table 3 summarizes the prevalence of helminthes in vegetable samples. Comparative analysis of the prevalence of helminthes in the three samples showed that Ascaris lumbricoides was the most prevalent helminth in refuse dumps and farmland soil samples while hookworm was the most prevalent in vegetable samples. Taenia solium and Taenia saginata were found only in samples from refuse dump sites but none from garden soil and / or vegetable samples Statistical analysis of the data using ANOVA showed strong positive correlation $(\mathrm{p}<0.0 .5)$ in the prevalence of intestinal helminthes between the refuse disposal dump sites and soil / vegetable samples collected from nearby cultivated farms and gardens. Amaranthus hybidus leaves harboured more helminthes than Telfairia occidentalis. 
The Impact of Refuse Disposal Dump Sites on the Spread of Intestinal Helminthiasis in Owerri Metropolis, IMO State, South Eastern Nigeria

Table1. Prevalence of Helminthes in Refuse dumps samples

\begin{tabular}{|c|c|c|c|c|c|c|c|c|}
\hline \multirow[t]{2}{*}{ Sample Site } & \multirow{2}{*}{$\begin{array}{c}\text { No } \\
\text { Exam }\end{array}$} & \multicolumn{7}{|c|}{ Number Infected (\%) } \\
\hline & & \begin{tabular}{|c|} 
Ascaris \\
lumbricoides
\end{tabular} & $\begin{array}{l}\text { Trichuris } \\
\text { trichiura }\end{array}$ & Enterobius & $\begin{array}{l}\text { Taenia } \\
\text { solium }\end{array}$ & $\begin{array}{l}\text { Taenia } \\
\text { sagina }\end{array}$ & $\begin{array}{c}\text { Hookwo } \\
\text { rm }\end{array}$ & Strongloidesy \\
\hline Egbu & 2 & $1(50)$ & & & & $2(100)$ & $1(50)$ & \\
\hline Irete & 4 & $2(50)$ & 1(25) & & & & $1(25)$ & \\
\hline Concord & 2 & $1(50)$ & $1(50)$ & & & & 1(50) & \\
\hline $\begin{array}{l}\text { Amakohia/ } \\
\text { Akwakuma }\end{array}$ & 4 & $3(75)$ & $2(50)$ & $1(25)$ & $2(50)$ & & $2(50)$ & \\
\hline Relief Market & 2 & & $1(50)$ & & 1(50) & & & $1(50)$ \\
\hline World Bank & 4 & 1(25) & & 1(25) & & $2(50)$ & 1(25) & $1(25)$ \\
\hline $\begin{array}{l}\text { Emmanuel } \\
\text { College }\end{array}$ & 2 & $1(50)$ & & & 1(50) & & $1(50)$ & \\
\hline Ikenegbu & 2 & & 1(75) & & & $1(50)$ & 1(50) & \\
\hline Orji & 4 & 3(75) & & $2(50)$ & & & $1(25)$ & $1(25)$ \\
\hline Nekede & 4 & $2(50)$ & & & 1(25) & & $3(75)$ & $1(25)$ \\
\hline Total & 30 & 14(46.7) & $6(20)$ & 4(13.3) & $5(16.7)$ & $5(16.7)$ & $12(40)$ & 4(13.3) \\
\hline
\end{tabular}

Table2. Prevalence of Helminthes in soil samples from near - by Farmlands

\begin{tabular}{|c|c|c|c|c|c|c|}
\hline \multirow[t]{2}{*}{ Sample Site } & \multirow{2}{*}{$\begin{array}{c}\text { Number } \\
\text { Exam }\end{array}$} & \multicolumn{5}{|c|}{ Number Infected } \\
\hline & & $\begin{array}{c}\text { Ascaris } \\
\text { lumbricoides }\end{array}$ & $\begin{array}{l}\text { Trichuris } \\
\text { trichiura }\end{array}$ & Hookworm & $\begin{array}{c}\text { Strongyloides } \\
\text { stercoralis }\end{array}$ & $\begin{array}{c}\text { Enterobius } \\
\text { vermicularis }\end{array}$ \\
\hline Egbu & 2 & $1(50)$ & & $2(100)$ & & \\
\hline Irete & 4 & $3(75)$ & & $2(50)$ & & \\
\hline Concord & 2 & $1(50)$ & 1(50) & 1(50) & & \\
\hline $\begin{array}{l}\text { Amakohia/ } \\
\text { Akwakuma }\end{array}$ & 4 & $2(50)$ & $2(50)$ & $2(50)$ & & $1(25)$ \\
\hline Relief Market & 2 & & 1(50) & & 1(50) & \\
\hline World Bank & 4 & $1(25)$ & & $1(25)$ & $2(50)$ & $2(50)$ \\
\hline $\begin{array}{l}\text { Emmanuel } \\
\text { College }\end{array}$ & 2 & $1(50)$ & & $2(100)$ & & \\
\hline Ikenegbu & 2 & & $1(50)$ & $1(50)$ & & \\
\hline Orji & 4 & $2(50)$ & & $2(50)$ & $2(50)$ & $2(50)$ \\
\hline Nekede & 4 & $3(75)$ & & 3(75) & $2(50)$ & \\
\hline Total & 30 & $20(66.7)$ & $8(26.7)$ & $17(56.7)$ & $8(26.7)$ & $5(16.7)$ \\
\hline
\end{tabular}

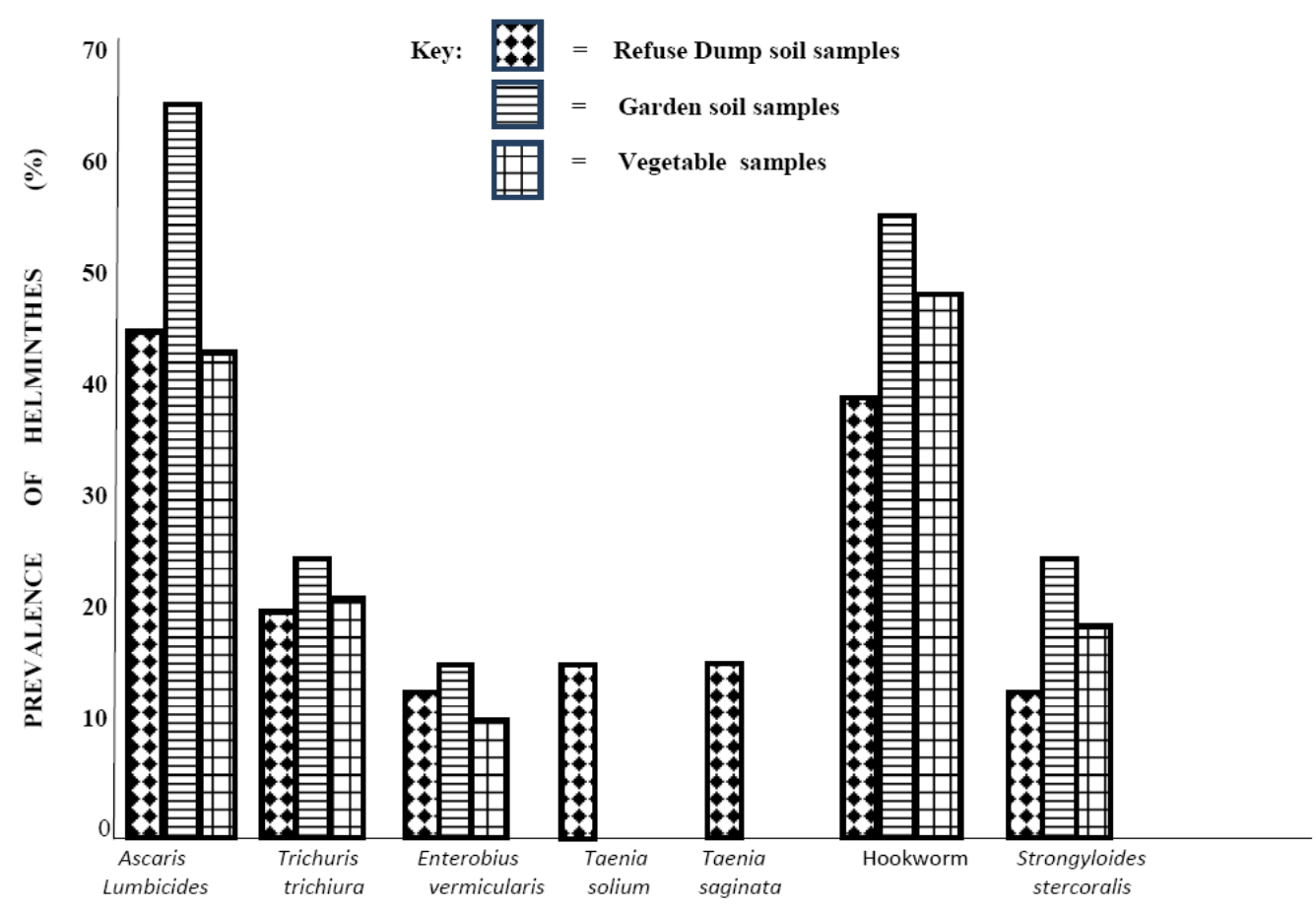

Fig1. Comparative analysis of prevalence of helminthes in test samples 


\section{DISCUSSION}

Over the years, the prevalence of intestinal helminthiasis in Imo State has remained on the increase (Obiajuru and Ogbulie, 2005). A number of factors have been blamed, ranging from poor environmental sanitation especially in the urban areas to lack of public health education (Obiajuru and Ogbulie, 2003). Following the regular monthly environmental exercise in Imo and some other states in Nigeria and prompt evacuation of the generated wastes, Imo State appeared to have enjoyed improved sanitation. In the last two years, there appears to be significant decline in this exercise. When monthly environmental sanitation holds, the refuse dumps are abandoned for weeks without evacuation. Domestic animals (goats, dogs, etc.) rodents and pests feed indiscriminately from these wastes. Children and adults often visit these refuse dumps searching for metal scraps and broken plastics etc. which they gather and sell to people who recycle them for production of industrial raw materials. The present study showed that these refuse dumps located in different parts of owerri metropolis are not safe for both humans and animals. The correlation between the parasites found in these refuse dumps and nearby farmland and vegetables suggest that these refuse dumps are sources of intestinal parasites found in both soils and farm vegetables in Owerri metropolis. The infested soil and vegetables pose great public health risks to the population. Farmers who work in the farms and consumers of the farm products such as vegetables are the major risk group. The socio - economic impact of helminthes infections are enormous. Some school children have missed school for day or weeks due to worm infections and some low income families have spent moneys meant for other projects to treat infected family members. Worm infections have also been associated with other complications such as malnutrition, iron deficiency anaemia, and mental illness (Watkins and Pollitt, 1997). Imo State Environmental protection agency (ISEPA) and Environmental transformation Cooperation (ENTRACO) should take advantage of this study and ensure prompt evacuation of the wastes to avoid spreading infectious agents in the neighbourhood. Farmers working in nearby farmlands should wear boots and adopt protective measures to prevent infections. Consumers of the farm products like vegetables should wash them thoroughly and cook them very well before consumption.

The consequences of helminthes infections are many, for instance, immune response triggered by helminthes infection may drain the body's ability to fight other diseases, exposing infected persons to secondary infections (Chammartin, et al., 2013). Previous workers (Anthony et al., 2007) have linked helminthiasis to unrelenting prevalence of HIV / AIDS and tuberculosis in developing countries, particularly in African. Other workers reported that effective treatment of helminthes infection reduces HIV progression and viral load, probably by improving helminthes induced immune suppression (McSarley and Maizels, 2002)

Intestinal helminthes impair the development of their human hosts by their impact on nutrition. Previous reports associated intestinal helminthes infection with vitamin deficiencies, stunting, anaemia, and protein-energy malnutrition, which in turn affect cognitive ability and intellectual development (Kumarendran et al., 2011). The gradual and relatively asymptomatic nature (Ogwurike et al., 2010) of this association makes it worrisome

Some of the helminthes isolated in the present study such as whipworm and Ascaris lumbricoides are believed to impact their hosts by competing directly with them for food (WHO, 2002; Kabatereme et al., 2005) Helminthes infection also causes loss of appetite and decline in food consumption (WHO, 2002). Some helminthes infection such as hookworms induces iron-deficiency anemia in the hosts. Hookworm (N. americanus and A. duodenale) feed directly on the blood of their host (Kumarendran et al., 2011). Helminthes infection, constitute a major barrier to children's progress in school. Those with heavy worm infections may be too weak to attend classes, or their families may be too indebted by medical bills and low worker productivity to pay for school enrollment fees.

Many countries like South American have controlled helminthes infection through Public health campaigns (Chammartin et al., 2013). According to some workers (Walson, et al., 2009; Mascarini Serra, 2011) deworming of school children has helped to control intestinal helminthes infections and prevent the spread of opportunistic infections. The nature of intestinal helminthes and available 
medications for treatment favour make universal deworming programs a step in the right direction. Helminthes infection is generally diffuse; therefore treating a wide population is a worthwhile venture. Also, anti-helminth drugs are readily available, cheap and safe to use. Many anti helminthic drugs can be used fairly effectively against many species of intestinal helminthes or any co-infection of different helminthes (WHO, 2002).

The present study has shown that refuse dumps located around different parts of Owerri, nearby farmlands and vegetables harvested in the farms harbor different species of helminthes capable of infecting human beings. Possibly, acute transmission and infections of these helminthes may have occurred over the time among the population. We therefore recommend periodic deworming of people especially school children in the study area as a means to protect them from the spread of infections which will cost much more to treat and manage. The Government and the environmental protection agency should take advantage of this study and step up action on timely and regular evacuation of refuse dumps around Owerri metropolis

\section{REFERENCES}

[1] Ahmed, A. B (2011): Insect Vectors of Pathogens in selected undisposed Refuse dumps in Kaduna town, Northern Nigeria. Science World Journal 6(4):174 - 181 ISSN: 1597 - 6343

[2] Anthony, R. M., Rutitzky, L. I., Urban, J. F. and Guase, W. C (2007): Protective Immune Metabolisms in Helminthic Infection. Nature Reviews Immunology 7(12): 975 - 987

[3] Chammartin, F., Scholte, R. C., Guimaraes, L. H., Tanner, M., Urzinger, J. and Vounatsou, P (2013): Soil Transmitted Helminths infections in South America: A Systematic review and Geostatistical Meta analysis. Lanest Infection Disease 14(3): 183

[4] Egwunyeenga, A and Ataikim, D. P. (2006): Soil Transmitted Helminths among school age children in Ethiopia East Local Government Area, Delta State. African Journal of Biotechnology 4(9): $938-941$

[5] Kabatereme, N. B., Tukahebula, E.M., Kazibwe, F (2005): Soil Transmitted Helminth in Uganda: Epidemology and cost control. Tropical Medicine Int. Health 10(11): 1187 - 1189

[6] Kumarendran, G. K., Gunasugha, E. R and de Silva, P (2011): Soil Transmitted Helminth infection among plantation sector school children in Siri Lanka: Prevalence after 10 years of preventive Chemotherapy. PLOSN egi Tropical Disease 5(9): 1341

[7] Mascarini - Serra, L (2011): Prevention of soil transmitted Helminth infection. Journal of Global Infectious disease 3(2): 175 - 182

[8] McSarley, H. J. and Maizels, R. M (2002): Helminth infections and host immune regulation. Clinical Microbiology reviews 25(4): 585 - 608

[9] Mordi, R. M. and Okeke, C. E (2009): Prevalence of Intestinal Parasites in Edo State Nigeria. Internationa Journal of Health Research. 2(3): 253 - 257

[10] Mordi, R. M., Momoh, M. I. and Borke, M. E (2012): Hookworm infection in Edo State Nigeria. Nigeria Journal of Parasitology 3(1): 67 - 72

[11] Obiajuru, I. O. C and Ogbulie, J. N (2003): Studies on the prevalence of Human intestinal parasites in Owerri, Imo State. Nigerian Journal of Microbiology. 17 (1): 57 - 62. ISSN 0794 1293.

[12] Obiajuru, I. O. C and Ogbulie, .J. N (2005): Prevalence of Intestinal Helminthiasis in parts of Imo State. Global Journal of Pure and Applied Sciences 11(1): 17 - 21 ISSN 1118 - 0579

[13] Obiajuru, I. O. C and Ozumba, U. C (2009): Laboratory Methods for Medical Microbiology and Parasitology. Lifeway Amalgamations. Owerri Nigeria. ISBN: 2579 - 9107 p. 183

[14] Ogwurike, B. A., Ajai, J. A. and Ajayi, O. O (2010): A Comparative Study of Helminthiasis Among Pupils of Private and Public Primary schools in Jos North Local Government Area of Plateau State Nigeria. Nigeria Annal of Natural Science 10(1): 28 - 41

[15] Opara, A. U, Nnodum, J. K and Nwachukwu, M. I (2011): Determination of Intestinal Parasite Load of Refuse Dumps and Strategies for Efficient waste Disposal in Owerri Municipal Council Area of Imo State Nigeri. Global Research Journal of Science. ISSN 2276-8300 
[16] Saka, M. I., Abduiraheen, J. S., Akanb, A. A and Musa, O. I (2006): Soil Transmitted Helminthiasis in Children: Evidence from School based Epidemological study in an urban Nigerian community. Nigeria Medical Practitioner 49(6): 148 - 153

[17] Walson, J. L, Herrin, B. R, and John-Stewart, G (2009): Walson, Judd. ed. "Deworming helminth co-infected individuals for delaying HIV disease progression". Cochrane Database of Systematic Reviews.

[18] Watkins W. E and Pollitt, E (1997): "'Stupidity or Worms': Do Intestinal Worms Impair Mental Performance?". Psychological Bulletin 121 (2): 171-91 PMID 9100486.

[19] World Health Organisation (2003): Reports of a WHO Expert Committee 912 Geneva. Prevention and Control of Schistosomiasis and Soil Transmitted Helminthiasis (Technical report) p.63

[20] World Health Organisation (2010): Soil Transmitted Helminths http//who.int/intestinalworms/ en/ updated sept. 